\title{
EDITORIAL
}

\section{In-Visibilidades: da gênesis presencial à realidade virtual}

O Congresso Ibero-Americano de Educação Artística - Arte/Educação, realizado em Beja (Portugal) em Maio de 2008, será um marco histórico para a arte/educação iberoamericana, porque de suas sessões e reuniões saíram algo mais que declarações e princípios. Nesse encontro, foram firmados os fundamentos que permitirão nos consolidarmos como uma realidade articulada à grande quantidade de iniciativas que conformam a Educação Artística - Arte/Educação em nossos países.

Basicamente se acordaram os principios de identidade da Rede e a estrutura de sua configuração. Sobre os primeiros, se acordou que seria uma rede rizomática e dinâmica, que vai crescendo ao ritmo que marca a atividade de seus membros. Decidiu-se que ela se organizará a partir de nós de atividade, sejam esses de caráter geográfico ou temático. Igualmente se acordou que seja uma rede livre, independente e autônoma, recolhendo toda a diversidade de tendências e inquietudes que hoje representam a arte/educação iberoamericana.

De acordo com esses principios, a estrutura que configura a rede se sustenta em três espaços de trabalho e ação:

- Um portal que se configure como lugar de encontro e intercâmbio de informação.

- Uma revista virtual de divulgação de pesquisas.

- Congressos que se celebrarão bi ou trienalmente.

É nesse contexto, portanto, que nasce a revista que hoje temos a satisfação de apresentar-lhes, como um complemento da ação de divulgação de experiências que oferece o portal web.

Como toda publicação recém-nascida, haverá que esperar que cresça um pouco, para ver como vai se conformando sua identidade, que, em grande medida, dependerá da quantidade e qualidade dos trabalhos que se apresentem para serem publicados. Mas o grupo de trabalho que lançou a iniciativa adotou distintas resoluções que marcam, desde sua gestação, a linha pela qual a revista quer fazer-se: um novo espaço no âmbito das publicações internacionais sobre arte/educação. No espírito do grupo gestor não se contemplava a ideia de apenas dar à luz uma publicação, mas sim de fazer uma revista de referência para o âmbito da educação iberoamericana, especialmente dirigida a uma urgente necessidade que temos de difundir os resultados de nossas pesquisas com periodicidade que propicie a circulação de novas questões, inquietações e debates (dois números por ano). 
Ainda no espírito do grupo, desde seu nascimento, se quer que a revista marque uma posição ante o monopólio da produção científica do saber da educação das artes, que desde há algumas décadas domina o mundo anglofalante. Obviamente, isso só será possível se forem colocados à disposição mecanismos que garantam a qualidade e diversidade do que se publica. Decidiu-se criar um Comité Editorial, composto por um grupo de 3 a 10 pessoas de diferentes países e um Conselho Científico e Avaliador, também de caráter internacional, composto por um grupo de 20 a 30 pessoas e aberto à possibilidade de inclusão de pesquisadores relevantes de outras áreas de interesse.

Em todo caso e apesar da ênfase na difusão da pesquisa e da reflexão, se tratará de lograr que a revista não fique excessivamente aprisionada no entorno acadêmico e que resultará útil para a formação de todo o professorado.

Como costuma acontecer nesses casos, a eleição de um nome foi o que mais debates e dúvidas suscitou, mas finalmente houve acordo comum em denominá-la In-Visibilidades (Revista Ibero-americana de Pesquisa em Educação, Cultura e Artes - Revista Ibero-Americana de Investigación en Educación, Cultura y Artes). Um título bilingue, como bilingue querem ser seus conteúdos, já que se poderá escrever indistintamente nas distintas variantes do português e do espanhol.

Este foi, portanto, o desafio e este número zero que hoje podemos desfrutar é o resultado deste ano de trabalho do Comitê que foi nomeado para colocar em marcha este projeto, que não significa somente a participação e aceitação da convivência entre países ibéricos e americanos de línguas portuguesa e espanhola. É um projeto que persegue integrar os saberes construídos nessas línguas, compartilhar os procedimentos e resultados das pesquisas e posicionarse ante o reconhecimento da importância que neste âmbito adquirem as áreas de conhecimento Educação, Cultura e Artes.

A partir de agora, a revista será um motivo a mais para que cresçam em nosso entorno a pesquisa e a reflexão sobre nossas ações educativas. E será um motivo a mais para nos animarmos a melhorar a qualidade de nossas publicações, porque somente desse modo poderemos levantar uma voz realmente alternativa ao domínio cultural anglofalante e uma visão que sirva de referência ao mundo iberoamericano.

Como seu próprio nome sugere, trata-se de que a revista cumpra sua função de fazer visível o "in-visível" e que convertamos suas páginas virtuais no coração do progresso da arte/educação iberoamericana. I

Imanol Aguirre Lucia Gouvêa Pimentel 